\title{
On translating mythological elements in literature: a posse ad esse
}

\author{
B. O. Pliushch
}

Assistant Professor, Taras Shevchenko National University of Kyiv, Kyiv, Ukraine

Corresponding author. E-mail: danapliushch@outlook.com

Paper received 05.02.21; Accepted for publication 15.02.21.

https://doi.org/10.31174/SEND-Ph2021-248IX73-19

\begin{abstract}
The article examines the specifics of translating myths in literature. It presents a case study of English and German translations of the drama "Lisova pisnya" (1911) by Lesya Ukrainka (1871-1913), a prominent Ukrainian author. The illustrative material of the study comprises not only German and English translations $(1931,1950)$ of the drama but also its most recent retranslations $(2006,2018$ respectively). The article provides an outline of the main priorities in translating any mythology-based discourse.
\end{abstract}

Keywords: myth, mythology, translation, retranslation, extra-linguistic determinants, charactonym.

Mythology represents a challenge for translation per se and interpretation in general. Whereas every educated person irrespective of their background, is familiar with the Fall of the Titans and other flamboyant narratives of the Ancient Greek mythology, every nation has it's own folklore and myth lore, which is more "local" by definition and possesses a challenge for translation. Moreover, the interconnection inbetween translation and mythology is indeed one of a kind since, according to the mythology scholar J. Campbell, "it would not be too much to say that myth is the secret opening through which the inexhaustible energies of the cosmos pour into human cultural manifestation" [3]. Thus, he states that myths teach meaning [3] and "translation is meaning" [2, p.86]. English translator and scholar D. Bellos suggests that "the only way of being sure whether an utterance has any meaning at all is to get someone to translate it for you" [2, p.80]. American literary critic and a great educator G. Steiner calls translation "conditio humana" and states that "every language act is a translation" [5, p. 1]. Thus, both mythology or mythological thinking and translation are the means of our understanding (or attempts at grasping) the reality/ life and its intricacies.

As stated above, myths of different origins reflect different kinds of "reality". They are rooted in the cultural identity of the nation and thus inevitably find their way to the literature. Thus, whenever a translator encounters any element of the mythological universe in the source text, extra-linguistic determinants of translation come to the fore. "The translator should make it possible for the reader in the TL to see and understand the text in terms of his own cultural context" [4, p.79]. This is how the German translation scholar K. Reiss explicated "the audience factor" [4, p.78]. The first woman to translate Homer's "Odyssey" into English, Emily Wilson, described the experience of translating a text full of mythological elements in the following way: "It is thinking about other cultures as well, not just thinking about where we are at this particular place in history. And that's thinking about the future as well as thinking about the past" [9]. Thus, mythological elements in the literary texts make the process of translation more challenging.

This article presents the case study of Ukrainian literature in English and German translations from the standpoint of mythological elements rendering. The illustrative material for the study comprises the drama (play) by a prominent Ukrainian author of the late XIX century - Lesya Ukrainka and its English and German translations. "Mavka. Lisova Pisnya" ("Mavka. Forest Song") is based on the Ukrainian mythology and folklore. The main protagonist of the play is Mavka. According to the Ukrainian Mythology Encyclopedia, mavky are "young beautiful girls, tall, with long hair, interwoven with flowers; their clothes is thin and transparent, they look as girls from the front but don't have bodies [...]" $[14$, p.285]. People used to call souls of the dead children mavky (the Plural of Mavka). Thus, even though Mavka is not represented in Germanic mythology, her "supernatural being" is comprehensible to an English or German reader - a young and extraordinarily beautiful "girl". Lesya Ukrainka creates a narrative, in which the main protagonists are a "forest princess" - Mavka - and a human - young man named Lukash. Thus, the idea of a romance between a man and a supernatural creature (an incredible beauty) is universal. "Die schönste Jungfrau sitzet/ Dort oben wunderbar, / Ihr goldnes Geschmeide blitzet, Sie kämmt ihr goldenes Haar [...]" (Die Lore-Ley, H. Heine, 1824). Renown German writer $\mathrm{H}$. Heine bases his prominent verse on the German folklore, depicting the alluring charm of the Mermaid (die Nixe/ die Meerjungfrau) in his "Märchen aus alten Zeiten" (fairy tale from the very old times). However, appearences are deceitful. The seeming similiraty of mythological creatures as well as ubiquity of supernatural love story do not make it easier for a translator to render a story based on Slavic mythology into a Germanic TL. The reader has to be provided with the explanation as to what is Mavka. Is it a nymph or else? And if it's a nymph, should it's name be rendered into English and German as Nymph/ die Nymphe? In the English translation of the drama by V. Tkacz and W. Phipps ("Mavka. The Forest Song", 2018) the list of characters comprises also the explanation/ explication of their mythological roles. Mavka in the list is defined as "woodland nymph" [12, p.135]. In 1950 English translation she is a "forest nymph" [11, p.169], which, despite woodland and forest being synonyms, is more appropriate due to the title of the drama - "Forest Song". Thus, the aforementioned examples illustrate the attempts of translators to familiarize the character of Mavka from the Ukrainian mythological universe, with the English speakingreader by adhering to the classics - Ancient Greek mythology. Encyclopaedia Britannica provides the following definition of a nymph: "[...] in Greek mythology, any of a large class of inferior female divinities. The nymphs were usually associated with fertile, growing things, such as trees, or with water. They were not immortal but were extremely long-lived and were on the whole kindly disposed toward men". [8] Indeed, the similitude is striking. However, the so-called "forest nymph" or "woodland nymph" has a name of its own in Greek mythology and it is a dryad: "a nymph or nature spirit who lives in trees and takes the form of a beautiful young woman". [6] Thus, Mavka in Ukrainian mythology has a direct correspondence in Greek and Germanic mythological universe Dryad. Sadly, both English translations of the drama include references to nymphs but not to dryads, which seems inconsistent and makes the representation of Mavka more general- 
ized than it is in the source text.

The latest German rendering of the work ("Das Waldlied. Feerie in drei Akten", 2006) by I. Katschaniuk-Spiech is devoid of any definitions or additional explanatory notes [13, p. 17], whereas in 1931 German translation ("Waldlied. Märchenspiel in 3 Aufzügen") by E. Bermann the following footnote can be found:

"Mawka - ein ungetauft gestorbenes Mädchen, dass sich in eine Waldfeld wandelte." [10, p.18]

(,Mavka - a drowned dead girl, who wanders in the forest $^{\text {") }}$

Thus, the first German translation provides more information as to the mythological origin of the main character. It is more precise then English translations of the work because the translator opted for providing a clear definition of mavky in Ukrainian mythology and a very important factor comes to the fore: in Ukrainian mythological tradition mavky are the souls of dead girls (who died tragically), whereas nymphs in Greek or Germanic mythological tradition are female divinities. Thus, Mavka as a character of the story possesses inherent tragic component, her fatalism is a default position and motivates her actions throughout the story. The latest German retranslation is more faithful to the original (it provides the list of characters without any explanatory notes) and thus is more source-oriented. However, it presupposes the foreign audience's familiarity with the source's mythological context. Otherwise, the reader's misinterpretation of the narrative is unavoidable.

Thus, the lack of explanatory material may not only incite misunderstanding of the Ukrainian mythological universe on the part of the foreign readership but also impede the interpretation of the characters' motives as well as the plot twists and the narrative in general.

If mavky can remind of the Ancient Greek nymphs, the rest of the mythological creatures-characters of "Mavka. Forest Song" is outlandish to the non-Slavic mythological universe. Lesya Ukrainka used Ukrainian folk lore and mythology for the creation of "Lisova pisnya" but she also made up some of the supernatural creatures. She combined and interconnected "real" mythological creatures and "her own" and thus created a unique mythological universe. When writing the maid-up mythological characters, Lesya Ukrainka adhered to charactonyms or speaking names. That is, she gave her fictional characters names that described them. Consider the following examples of the "list of characters":

a. а."Той, що греблі рве”

b. “Той, що в скалі сидить”

c. Куць [12, p. 5]

b. a."He Who Rends the Dikes," a destructive sprite dwelling in the freshets of spring

b. "He Who Dwells in Rock," a phantom signifying Death and Oblivion

c. Kutz, a malicious imp [11, p. 169]

c. a. Spring Flood, young male water spirit

b. Keeper of the Shadows, a spirit

c. Kutz, a male swamp spirit [12, p. 135]

d. a. „Der die Dämme einreisst"

b. "Der in dem Felsen wohnt"

c. Kuz [10, p.18] 1931

e. a. „Der die Dämme sprengt“

b. ,Der im Felsen sitzt“

c. Gnom [13,p. 17]

The characters' names from the examples a.a, a.b. ("The one who ruptures dikes", "The one who sits in the cliff") are rendered differently in two English translations. In the earlier rendering by P. Candy (examples b.a., b.b) the charactonyms are translated literally. Moreover, an English speaking reader is offered an explanations of the characters' roles, describing what do they represent. In the latest translation by V. Tkach and W. Phipps (example c.) the explanatory notes are also there but they are much shorter (examples b.b. and c.b.) and the charactonyms are rendered by creating new images Spring Flood, Keeper of the Shadows. In the example c.b. one can get confused as to what exactly the creature represents, is it a spirit of the Dead or Death? Such a free interpretation of the character can be attributed to the fact that it is probably the only character in the play that doesn't have any description. He is characterized by the context of the situation (He appears to take the dying Mavka with him). However, the confusion of interpretations of the other two characters (examples b. a., b. c. and c.a., c. c.) can not be justified since Lesya Ukrainka describes all the rest of the characters in the drama and this is how she depicted the ones from the examples a. a. and a. c.:

f. ...молодий, дуже білявий, синьоокий, з буйними $i$ разом плавкими рухами...[12, p. 7]

g. 3-за купини вискакує Куц̧ь, молоденький чортикпаничик [12, p. 54]

Thus, the reader get to know from the very first pages of the drama that "Той, що греблі рве" is "young, very blond, with blue eyes, with flamboyant and at the same time flowing motions..." (example f.). Consider the following English renderings of the original description:

f. a. He is a youth, very blond with blue eyes, who makes expansive motions as though he were swimming [11, p. 170]

f. b. ... a pale young man with blue eyes and flowing movements, runs along the stream [12, p. 137].

From the examples above it is clear that in the earlier English translation "a destructive sprite" at first becomes an attractive young men, which is similar to the original perception since the character is new for the source language reader as well and thus his description in the text presents new information. In the recent retranslation however, "a young male water spirit" is represented as a weak or sickly creature due to the usage of the adjective "pale", which is very often associated with "feeling not so good", and has nothing to do with being "blond", and the omission of the adjective flamboyant/ wide ("буйний"). The theme of "attractiveness and vivaciousness" of the character is disrupted and the protagonist himself is misrepresented. Thus, the narrative structure of the original is modified in the recent English retranslation due to the change in perception of the character.

In German translations of the charactonym from the example a.a. the mythological creature is represented by literal translation (examples d.a. and e.a.). The depiction of the character in the text of the play is full (without omissions) and very close to the original:

f. c. [...] jung, sehr hell, blauäugig, mit wilden und doch schwebenden Bewegungen [10, p. 21]

f. е. [...] ein Jüngling mit sehr hellem Haar und blauen Augen; seine Bewegungen sind dynamisch, jedoch fliessend $[13$, p. 21]

From a description like in the example f. c. or f. e. a reader can picture a strong and attractive young man, which was the author's original idea. This examples demonstrate that often translator's discursive presence is not required to reconstruct an "implied author" [1, p. 275] and considering the specificity of the mythological elements, paratexts are not 
always necessary, especially if the original frame of the character is not "internationally known" and remains to be discovered through the process of reading (example a.b.).

However, not all character names of the play were rendered accurately in German translations. Example a.c. includes a description of an unknown and unidentifiable mythological creature, which in Ukrainian can be interpreted as "extremely short" (the word "kuts" can be perceived as a blend of a longer colloquial adjective - kutsyi - which stands for short). Later on in the text, one can find a depiction of this enigmatic character, being very short as well - "young (Sir) imp" (example g.). The addition of "young Sir" creates a humorous impression of a character's playful nature, somewhat similar to a trickster. Adding such a radical adjective as "malicious" (example b. c.) in the 1950 English translation distorts the theme of "playfulness" and the "swamp spirit" (example c. c.) in the 2018 retranslation is incorrect, since there is no information or any indication of Kuts' belonging to the swamp or any water area. German 1931 translation provides its readers with $K u z$ character that can be associated with the German adjective kurz - "very short" and the original presentation of the character is not altered due to the lexical similarity of the words the charactornym is based on. However, in the 2006 retranslation the character is called Gnom (example e.c.), which seems odd, especially if we consider the fact that it's a transliteration of the Ukrainian translation of a dwarf: "In Teutonic and especially Scandinavian mythology and folklore, the term dwarf (Old Norse: dvergr) denoted a species of fairy inhabiting the interiors of mountains and the lower levels of mines. Dwarfs were of various types, all of small stature, some being no more than 18 inches $(45 \mathrm{~cm})$ high and others about the height of a twoyear-old child" [7] Thus, the creature has nothing in common with the original mythological character. Kuts' is young but there is no indication of him being dwarfish short (example $\mathrm{g})$. The clear misrepresentation of the character is illustrated in some of the following translations of the original characteristics: g. a. From behind the bushes Kutz jumps out. He is a youthful imp, like a manikin. [11, p. 206]

g. b. KUTZ, a young male goblin jumps out of the bushes. [12, p. 182]

g. c. Hinter einer kleinen Erhöhung hervor kommt $K u z$ gesprungen, ein junger Teufel [10, p. 63]

g. d. Von der Anhöhe springt der Gnom hervor, ein junges Teufelchen - kleiner Kavalier. [13, p. 95]

In both English translations the young playful trickster is clearly misrepresented by adding simile (like a manikin) and epithets (young male goblin), which are absent from the original. The earlier translation (example g. a.) focuses on him being dwarfish, the 2018 retranslation (example g. b.) adds "ugliness" of another well-known mythological creature - goblin (In the world best-seller "The Hobbit" J.R.R. Tolkien depicts goblins as clever, gloomy and very ugly killers, they invent machines of torture etc.). To say that such a representation of an original Kutz' character is erroneous would be an understatement. As to the German rendering of the character's description, the earlier 1931 version (example g. c.) remained faithful to the source text and emphasized his youth and his trickery nature. The 2006 German retranslation (example g. d.) continued developing to the theme of Kleinigkeit (Shortness), the logic of it being disputable. Thus, almost all the renderings of the fictional character's name and description are confusing, contradictory to the original, which distorts the perception of his actions as well as intervenes with the narrative of the whole drama, since the character at hand is one of the most relevant.

The article raises important questions about perception and interpreting of the mythological universe in literature. More importantly, the results of the comparative translation analysis demonstrate that the defining factor in rendering the mythological element in translation is certitude of interpretation, which enables faithful representation of characters and impedes the distortion of the original narrative structure in translation.

\section{REFERENCES}

1. Alvstad Cecilia. The translation pact // Cecilia Alvstad // Language and Literature. Journal of the Poetics and Linguistics. Special issue: Narration and Translation; [editor: Geoff Hall; assistant editors: Catherine Emmott, Joanna Gavins]. - London: Sage Publications Ltd., 2014. - Vol.23. - №3. - P. 270-284.;

2. Bellos D. Is that a Fish in Your Ear? The Amazing Adventure of Translation / D. Bellos. - London: Penguin Books, 2012.-390 p.;

3. Mark J.J. Mythology // Joshua J. Mark // Ancient History Encyclopedia, $\quad$ October 2018. https://www.ancient.eu/mythology/;

4. Reiss K. Translation Criticism - the Potentials and Limitations. Categories and Criteria for Translation Quality Assessment. / K. Reiss, tr. by Erroll F. Rhodes. - Manchester: St. Jerome Publishing, UK\&Kinderhook (NY), USA, 2000. - 127 p.;

5. Steiner G. Translation as conditio humana // George Steiner // Übersetzung Translation Traduction. Ein internationals Handbuch zur Übersezungsforschung. (Herausgegeben von H. Kittel, A. Paul Frank, N.Greiner, T. Hermans etc) V1. - Walter de Gruyter, Berlin, Boston, 2004. - P.1-10;

6. The editors of Encyclopaedia Britannica (A. Augustun, A. Zeidan, A. Zelasko etc.). Dryad. Greek Mythology // The editors of Encyclopaedia Britannica (Adam Augustun, Adam Zeidan, Alicja Zelasko etc.). - https://www.britannica.com/topic/dryad;

7. The editors of Encyclopaedia Britannica (A. Augustun, A. Zeidan, A. Zelasko etc.). Dwarf. Greek Mythology // The editors of Encyclopaedia Britannica (Adam Augustun, Adam Zeidan, Alicja Zelasko etc.). - https://www.britannica.com/topic/dwarf-

mythology;

8. The editors of Encyclopaedia Britannica (A. Augustun, A. Zeidan, A. Zelasko etc.). Nymph. Greek Mythology // The editors of Encyclopaedia Britannica (Adam Augustun, Adam Zeidan, Alicja Zelasko etc.). - https://www.britannica.com/topic/nymph-Greekmythology;

9. Turner P. Emily Wilson on Translating Ancient Texts and the Place of Mythology Today / Parrish Turner // Culture Trip, August 22, 2018. https://theculturetrip.com/europe/greece/articles/emily-wilsonon-translating-ancient-texts-and-the-place-of-mythology-today/;

10. Ukrainka Lessja. Waldlied. Märchenspiel in 3 Aufzügen / Lessja Ukrainka; Deutsch von E. Bermann. - Charkiw, Kijiw: Staatsverlag „Literatur und Kunst“, 1931. - 134p.;

11. Ukrainka Lesya. Forest Song / Lesya Ukrainka // Spirit of Flame: A Collection of the Works of Lesya Ukrainka. Translated by Percival Cundy. New York: Bookman Associates, 1950. - P. 171-260;

12. Ukrainka Lesya. Mavka. The Forest Song / Lesya Ukrainka; tr. into English by V. Tkacz and W. Phipps. - Publishing Book House Kiev, 2018. - 256 p.;

13. Ukrajinka Lessja. Das Waldlied. Feerie in drei Akten / Lessja Ukrajinka; ins Deutsche übertragen von Irena KatschaniukSpiech. - Lwiw: Verlagszentrum der Nationalen Iwan-FrankoUniversität Lwiw, 2006. - 224p.;

14. Voytovych V. Ukrainian mythology/ Valeriy Voytovych. - K.: Lybid', 2002. - 664 p. 